\title{
Pathophysiological reasons for the failure of the cerebral perivascular drainage and progression of Alzheimer's disease
}

\author{
Nikola Barić \\ Presika 153, 52220 Labin, Croatia
}

OPEN ACCESS

Correspondence: Nikola Barić MD, PhD nikola.baric@pu.t-com.hr

This article was submitted to RAD CASA - Medical Sciences as the original article

Conflict of Interest Statement: The authors declare that the research was conducted in the absence of any commercial or financial relationships that could be construed as a potential conflict of interest.

Received: 25 October 2020 Accepted: 17 November 2020 Published: 28 December 2020

Citation:

Barić N. Pathophysiological reasons for the failure of the cerebral perivascular drainage and progression of Alzheimer's disease

RAD CASA - Medical Sciences. 544=52-53 (2020): 42-54 DOI: https://dx.doi.org/10.21857/ y54jofkxqm

Copyright (C) 2020 Barić N. This is an open-access article distributed under the terms of the Creative Commons Attribution License (CC BY). The use, distribution or reproduction in other forums is permitted, provided the original author(s) and the copyright owners(s) are credited and that the original publication in this journal is cited, in accordance whit accepted adacemic practice. No use, distribution or reproduction is permitted which does not comply with these terms.

\begin{abstract}
:
The disorder of intracerebral perivascular drainage of amyloid beta (A $\beta)$, as well as the drainage of various waste products related to a number of permanent biochemical reactions and physiological processes, leads to brain homeostasis disorders, breakdown of essential vital functions and rapid course of genetically programmed Alzheimer's disease. As the brain does not have its own standard glymphatic system, this important function is mostly taken over by the perivascular system located within the basement membranes of capillaries, arterioles and arteries. The crucial driving force of this drainage, according to recent investigations, is conditioned by the internal force of arterial and arteriolar walls, the so-called vasomotion. With the direction opposite from the direction of the blood stream and pulse wave, this pulsating force is based on rhythmic intracellular oscillations of $\mathrm{Ca}^{2+}$ ion concentration in vascular smooth muscle cells. These oscilations are the fundament of the vasomotion phenomenon, and their disorder leads to perivascular drainage alterations and severe complications. The aim of this review is to present a detailed analysis of crucial events that are important for perivascular drainage system alterations.
\end{abstract}

KEYWORDS: Alzheimer's disease, perivascular drainage alterations, glymphatic system, vasomotion phenomenon

\section{SAŽETAK:}

PATOFIZIOLOŠKI UZROCI POREMEĆAJA MOŽDANE PERIVASKULARNE DRENAŽE I PROGRESIJE ALZHEIMEROVE BOLESTI

Poremećaj intracerebralne perivaskularne drenaže amyloida beta $(A \beta)$, kao i drenaže različitih otpadnih produkata, nastalih tijekom brojnih permanentnih biokemijskih reakcija i fizioloških procesa, vodi do poremećaja moždane homeostaze, raspada osnovnih vitalnih funkcija, te ubrzanog tijeka genetski programirane Alzheimerove bolesti. Obzirom na činjenicu kako mozak nema svoj standardni glimfatički sustav, ta je važna funkcija preuzeta sa strane perivaskularnog sustava lociranog unutar bazalnih membrana kapilara, arteriola i arterija. Presudna pokretačka snaga te drenaže, na osnovu najnovijih istraživanja, bazira se na urođenoj sili arterijalnih i arteriolarnih zidova, tzv. vazomociji. Smjerom suprotnim od smjera krvne struje i vala pulsa, ta pulzirajuća sila bazira se na ritmičkim intracelularnim oscilacijama koncentracije $\mathrm{Ca}^{2+}$ iona unutar vaskularnih glatkih mišićnih stanica. Te oscilacije su baza fenomena vazomocije, a njihov poremećaj vodi do alteracija perivaskularne drenaže i teških komplikacija. Namjera ove studije je da prikaže detaljnu analizu presudnih zbivanja koji su važni za alteracije perivaskularnog drenažnog sustava.

KLJUČNE RIJEČI: Alzheimerova bolest, perivaskularni drenažni poremećaji, glimfatički susta, fenomen vazomocije 


\section{INTRODUCTION}

Due to the increasing rise of $\mathrm{AD}$ incidence and prevalence, Alzheimer's disease is becoming one of the crucial problems of modern society. The world population is increasingly older, absolutely and relatively, and $\mathrm{AD}$ is closely connected with age and aging. This neurodegenerative disease with a chronic and progressive course is marked with a progressive decline of memory, disorientation, and general drop of cognitive functions. The costs for its prevention and therapy exponentially grow. By removing other nonconventional brain lymphatic drainage pathways (the glymphatic system) from the analytic process, which include drainage across the blood brain barrier (BBB), blood cerebrospinal fluid barrier (BCSFB), choroid plexus, arachnoid granulationes (AGs), paravascular drainage (connected with the cerebral vasculature surfaces), perineural drainage, lymphatic drainage through the orbits into the sinus sagitalis superior, and nasal cavity (lymph inflow along the olfactory tract), this study is exclusively oriented to the perivascular drainage analysis $\left.{ }^{1-6}\right)$. Without entering the extensive and complex analysis of the complete cerebral drainage system, the aim of this review is to explain the crucial elements in events connected with the functioning of the perivascuar drainage pathway.

\section{Alterations of the perivascular drainage PATHWAY FROM THE BRAIN}

Alzheimer's disease, with its poligenetic but yet unknown ethiology, is a severe, chronic, and lethal neurodegenerative phenomenon, in which the inadequate drainage of elevated concentrations of $A \beta$, of iron ions and waste products out from the brain, leads to intracerebral accumulation of these ingredients, with evidently progressive deteriorative effects on brain homeostasis, and through time, to the occurence of a lethal end. This altered drainage is clearly connected with the aging process. Due to the permanent aging of the world population (senectual explosion), $\mathrm{AD}$ is becoming increasingly a crucial problem of the present-day human society. The two forms of this disease, the early form or EOAD (early onset AD-before the age of 65; APP gene-chr. 21q21.3; PSEN-1 gene-chr.14q24.2; PSEN-2 genechr.1q42.13; $B A C E-1$ gene-chr.11q23.3), and LOAD (late onset of AD-65 and more; ADAM10 gene-chr.15q21.3; APOE genechr.19q13.32) have practically the same clinical picture with the progressive loss of memory, loss of speech, and dramatic failure of cognitive functions ${ }^{2,7,8}$ ).

It is important to analyze some crucial events in $A \beta$ and iron metabolism, which are in the centre of the AD pathophysiology. Bound with transferin (Tf), two ferric ions $\left(\mathrm{Fe}^{3+}\right)$, in the form of $\mathrm{TfR} / \mathrm{Tf} / \mathrm{Fe}^{3+}$ complex, enter from the blood into the endothelial cell membrane and into its embeded endosomes. In these structures, the transferin receptor (TfR) is detached from the complex, and $\mathrm{Fe}^{3+}$ is reduced by ferric reductase located on the endosome membrane in $\mathrm{Fe}^{2+}$, and by the divalent metal transporter 1
(DMT1) and ferroportin (FPN1) transported into the neuropil. The detached TfR recycles back to the luminal cell membrane. $\mathrm{Fe}^{2+}$ in the neuropil is partially captured by DMT1 belonging to the neurons and microglia and becomes incorporated in their metabolism or stored as ferritin. The great part of $\mathrm{Fe}^{2+}$ is oxidized (loss of the electron) in $\mathrm{Fe}^{3+}$ by the locally present amyloid precursor protein (APP) and ceruloplasmin (CP) derived from the cell membranes. One part of $\mathrm{Fe}^{3+}$ bound with Tf/TfR enters into the adjoining cells, where it is used for their metabolic necessity or also stored as ferritin. A part of $\mathrm{Fe}^{3+}$ is attracted to the $\mathrm{A} \beta$ monomers and enters the oxido/reductive cycle with the resulting Fenton reaction and ${ }^{*} \mathrm{OH}$ generation. On the other hand, $A \beta$, by its intracellular (proteasome and ubiquitin-proteasome route, lysosomal cathepsin enzymes, metalloendopeptidases) and extracellular (neprilysin, matrix-metalloproteinases 2,3 and 9) degradation, is exposed to its elimination and iron ions discharge. It is evident that in the case of $A \beta$ overproduction typical for $\mathrm{AD}$, in the neuropil occurs the rise of $\mathrm{A} \beta$ concentration and the accompanying rise of iron ions. Due to these events, the effective drainage of elevated concentration of both compounds, $A \beta$ and iron ions, is necessary. This drainage is primarily obtained by the perivascular drainage pathway (Fig.1 $)^{6,7}$ ).

\section{ELEMENTARY CHARACTERISTICS OF THE PERIVASCULAR DRAINAGE PATHWAY}

This study deals with the central parts of arterial, arteriolar and capillary walls, the basement membranes of vascular smooth muscle cells (VSMCs), the VSMCs, the ground substance of the interstitium, as well as with the local structures such as elastin and collagen fibers, cell receptors, and a lot of diverse stationary or moving dissolved molecules.

The perivascular drainage pathway, limited by the outer and inner basement membranes of vascular smooth muscle cells (VSMCs), comprised by central media location, actually is a tridimensional poroelastic net, along which pass collagen and elastic fibers. The average thickness of each VSMCs membrane which encircles every cell, is in the range of $20-200 \mathrm{~nm}(1 \mathrm{~nm}$ $=1^{*} 10^{-9} \mathrm{~m}$, nanometer). Its tridimensional net is predominantly composed of proteins i.e. laminins, collagen IV, nidogens, and heparan sulfate proteoglycans (HSPG). There are also expressed many other proteins like the insoluble fibronectin, fibulin 1 and 2, collagen type XVIII, thrombospondins1, and secreted protein acidic and rich in cysteine (SPARC). The fundamental element of this drainage pathway, crucial for the transport of molecules and particles, is the ground substance, an amorphous gel-like substance primarily composed of water, in which are embedded the mentioned fibrils and molecules. The starting point of this pathway is located in BBB capillaries, i.e. in their basement membranes (Fig. 2-4) ${ }^{2-4,9}$ ). 


\section{DRIVING FORCES FOR PERIVASCULAR DRAINAGE}

The driving force for moving different particles and molecular complexes along this pathway in the direction opposite to the blood stream and pulse wave, is the recently in detail analyzed, but already previously discovered and not satisfactory explained, internal force of arterial and arteriolar walls, the so-called vasomotion. This pulsating force is based on rhythmic intracellular oscillations of $\mathrm{Ca}^{2+}$ ion concentrations in vascular smooth muscle cells. These oscillations cause the vasomotion phenomenon and their disturbance leads to perivascular drainage alterations and severe complications. ${ }^{4,6,10,11}$ ).

\section{THE CRUCIAL FAILURES IN THE DRIVING FORCES MECHANISM}

The crucial failures in the mechanisms responsible for regular perivascular drainage are primarily dependent on the elevated lipid peroxidation of VSMCs cell membranes, induced by free radicals. The regular contraction of these cells is important for the adequate generation of pressure gradient along the interior of arterial and arteriolar walls. The disruption of this adequate pressure gradient generation, primarily due to the VSMCs membranes lipid peroxidation, leads to the drop of cell contraction strength and decline of the vasomotion and drainage velocity. Lipid peroxidation of VSMCs membranes is a permanent spontaneous process, but normally there are effective protective forces to combat with free radical effects and thus repair the alterations. In Alzheimer's disease (AD), the oxidative stress is elevated. The generation of reactive oxygen species (ROS), especially free radicals with the crucial compound hydroxyl radical $\left({ }^{*} \mathrm{OH}\right)$, is significantly elevated. The repair deffensive forces are now not capable to combat and repair the failures in cell membranes structure $\left.^{4,6,10,11}\right)$.

\section{LIPID PEROXIDATION}

Cell membranes, especially their main structural elements, polyunsaturated fatty acids (PUFAs), are enormously lean towards the destructive action of hydroxyl radical $\left({ }^{*} \mathrm{OH}\right)$, one of the strongest member of free radicals, i.e. $\mathrm{ROS} .{ }^{*} \mathrm{OH}$ is primarily generated during the Fenton reaction $\left(\mathrm{Fe}^{2+}+\mathrm{H}_{2} \mathrm{O}_{2}=\mathrm{Fe}^{3+}+\right.$ - $\mathrm{OH}+{ }^{*} \mathrm{OH}$, which includes ferrous iron, hydrogen peroxide, hydroxyl ion, and ferric iron), extensively expanded practically in all tissues of $\mathrm{AD}$ patients. However, on account of the extremely great oxygen consumption, and the great quantity of polyunsaturated fatty acids, the brain is especially prone to ${ }^{*} \mathrm{OH}$ and strong spontaneous lipid peroxidation. The initiation of this destructive process occurs by the random crash between the free ${ }^{*} \mathrm{OH}$ molecule and hydrogen atom $(\mathrm{H})$ on polyunsaturated fatty acid (PUFA) methylene group $\left(-\mathrm{CH}_{2}-\right)$, between two double bonds, i.e. bis allylic hydrogen atom. Carbon-hydrogen $(\mathrm{C}-\mathrm{H})$ bond energy, due to the presence of the adjacent double bonds is very low and allows the $\mathrm{H}$ atoms to be readily abstracted by
${ }^{*} \mathrm{OH}$. The consequence is the formation of the carbon centred radical on the carbon 2py orbital, the bonding of the abstracted hydrogen (electron in the 1s orbital) with the unpaired electron in the 2 py orbital of ${ }^{*} \mathrm{OH}$, and the formation of neutral $\mathrm{H} 2 \mathrm{O}$ molecule, water (Fig. 5) ${ }^{12-16}$ ).

The next step is the phospholipid carbon centred radical reaction with the molecular oxygen $\left(\mathrm{O}_{2}\right)$ and the formation of peroxyl radical $\left(\mathrm{LOO}^{*}\right)$. By reacting with the new PUFA, peroxyl radical generates the new lipid radical $\left(\mathrm{L}^{*}\right)$ and lipid hydroperoxide $(\mathrm{LOOH}) . \mathrm{L}^{*}$ reacts with molecular $\mathrm{O}_{2}$ with the formation of new lipid peroxide (LOO*). This spontaneous reaction continues till the end, induced by the interplay of free radical scavengers, or by the mutual reaction of two ${ }^{*} \mathrm{OH}$ to form non-radical products (Fig. 5$)^{12}$ ).

It is also necessary to mention that a number of lipid peroxidation products and by-products is very destructive by inducing oxidative stress, oxidative damage and apoptosis. This is especially related to hydroperoxides and their aldehyde derivatives. Among aldehydes, most important is the 4-hydroxinonenal (HNE), the most effective product of lipid peroxidation, which induces evident cellular damage. Malonyl aldehide (MDA) also produces protein damage $\left.{ }^{13}\right)$.

\section{LipIDATION OF APOEE4 LIPOPROTEIN}

Apolipoprotein E (ApoE, 299 AA) encoded by the APOE gene (19q13.32) has a crucial role in $A \beta$ drainage along the perivascular pathway. This gene exists as three polymorphic alleles: ع2-112Cys, 145Arg, 156Cys; E3-112 Cys, 145Arg, 156Arg; and \&4-112Arg, 145Arg, 156Arg; with the worldwide frequency of $\varepsilon 2-8.4 \%$, $\varepsilon 3-77 \%$, and $\varepsilon 4-13.7 \%$ (AD frequency: $\varepsilon 2-3.9 \%$, $\varepsilon 3-$ $59.4 \%, \varepsilon 4-36.7 \%)$. Produced in the brain neuropil by astrocytes, at the capillary level (BBB), ApoE enters into the capillary basement membrane and continues its moving, induced by vasomotion, along the cortical and leptomeningeal arteries perivascular drainage pathway. During this moving (ApoE particle) it contacts high density lipoprotein (HDL) (primarily) and low density lipoprotein (LDL) particles and becomes lipidated by ABCA1 receptor expressed at the abluminal side of the blood brain barrier (BBB) endothelial cells. Lipidation (covalent binding of a lipid to a peptide chain) of ApoE induces evidently better solubility of lipid particle and much better drainage of the developed complex ApoE/lipid. Studies show that $\varepsilon 4$ allele is the evident risk factor for Alzheimer's disease (AD). Similar to the letter L, ApoE has two domains: N-terminal domain, res. 1-167 and C-terminal domain, res. 206-299. Between them lies the hinge region, res. 165-205. It is also necessary to mention the receptor binding region, res. 136-150, and the lipid binding region, res. 244-272. It is important to emphasize that besides the astrocytes, the main producers of ApoE in the brain are also choroid plexus epithelial cells and microglia (Fig.4). 

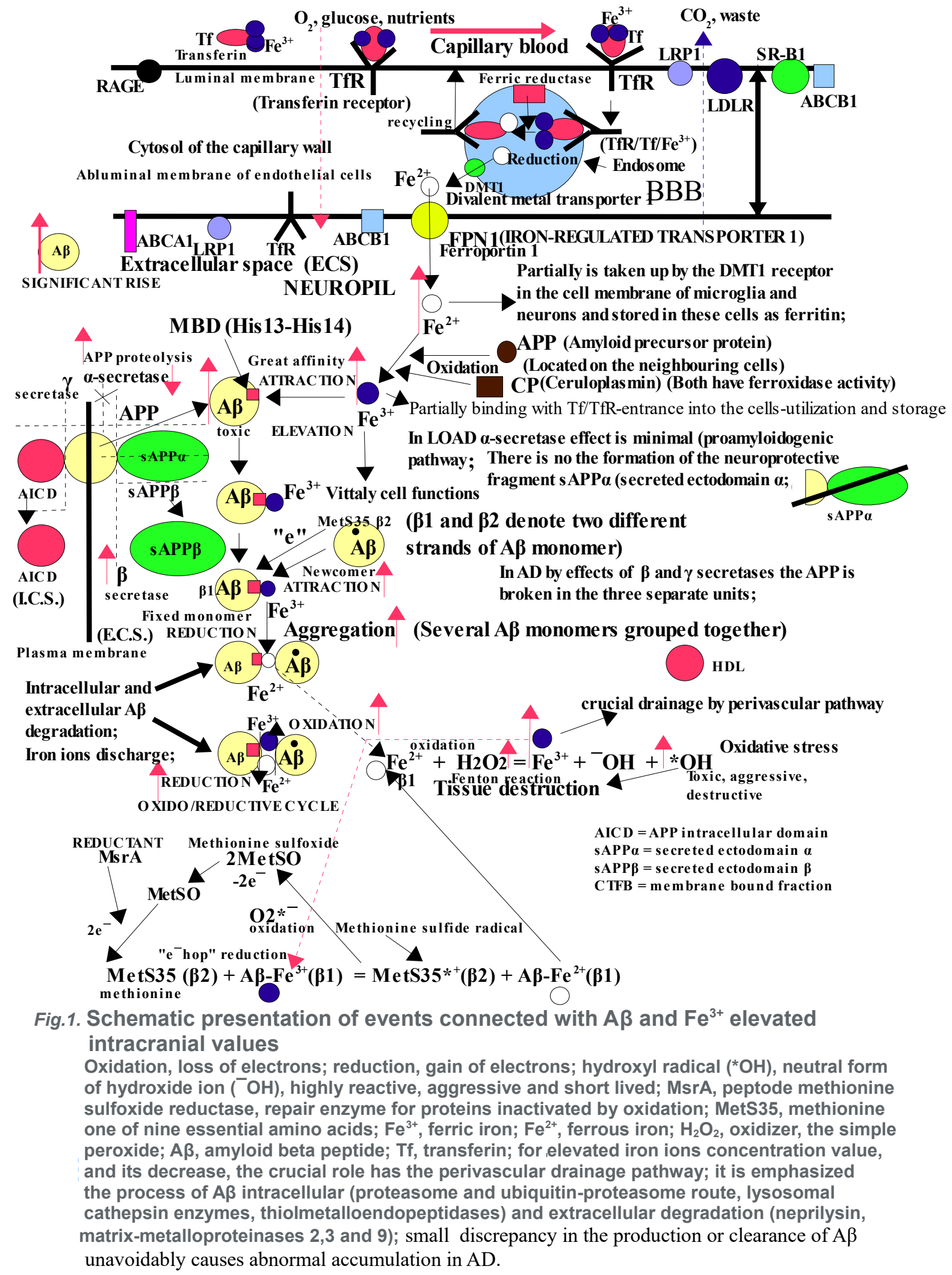

$\beta 2$ ( $\beta 1$ and $\beta 2$ denote two different

sAPPa 


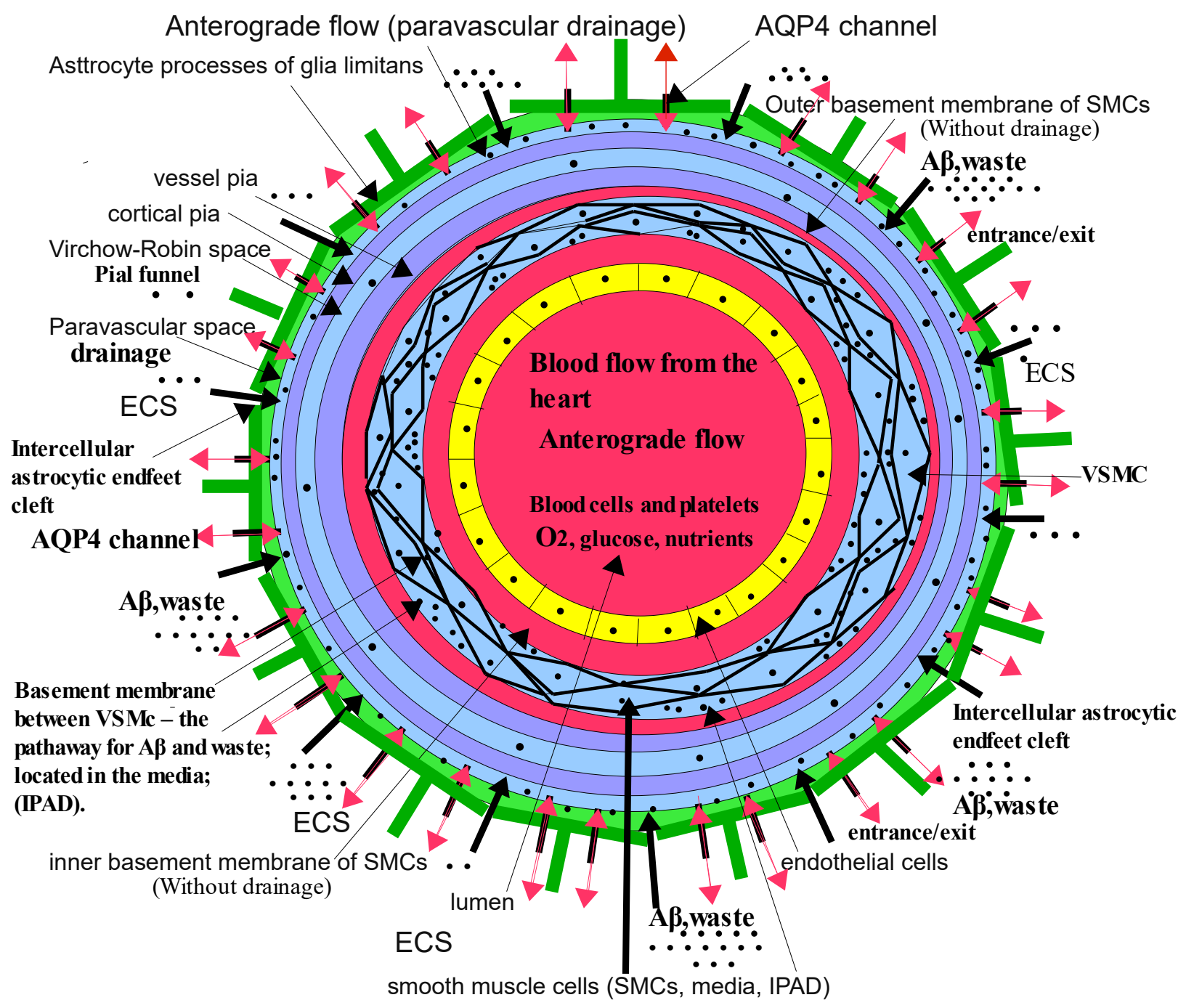

RETROGRADE FLOW OF WASTE AND A $\beta$ - perivascular drainage

\section{Fig.2. Schematic presentation of the penetrate artery cross section}

Clearly presented is the cross section of the cerebral parenchymal penetrating artery. By different colours are visible the essential artery layers including intra-mural peri-arterial drainage IPAD) pathway and paravascular drainage pathway. By dark green colour are designated the astrocytic endfeets, and between them by black arrows intercellular astrocytic endfeet clefts. By small black rectangles, covered with bidirectional arrows, are presented the AQP4 channels, important for entrance in the artery wall and exit from it, of a lot of solutions and $A \beta$ peptide. The big black arrow shows the most important layer in the artery wall, the media, and in its structures, located between vascular smooth muscle cells, the perivascular drainage pathway (black points in layers between the mentioned cells). Black points in the extracellular space (ECS) represent $A \beta$ and waste. Between cortical and vessel pia there is Virchow-Robin space. On the outer side of the cortical pia, coloured by light blue colour, there is visible the paravascular drainage pathway. Cross section presents the situation on the middle level of the Virchow-Robin space. SMCs are in the relaxed phase of the vasomotion wave. 
Subdural cavity

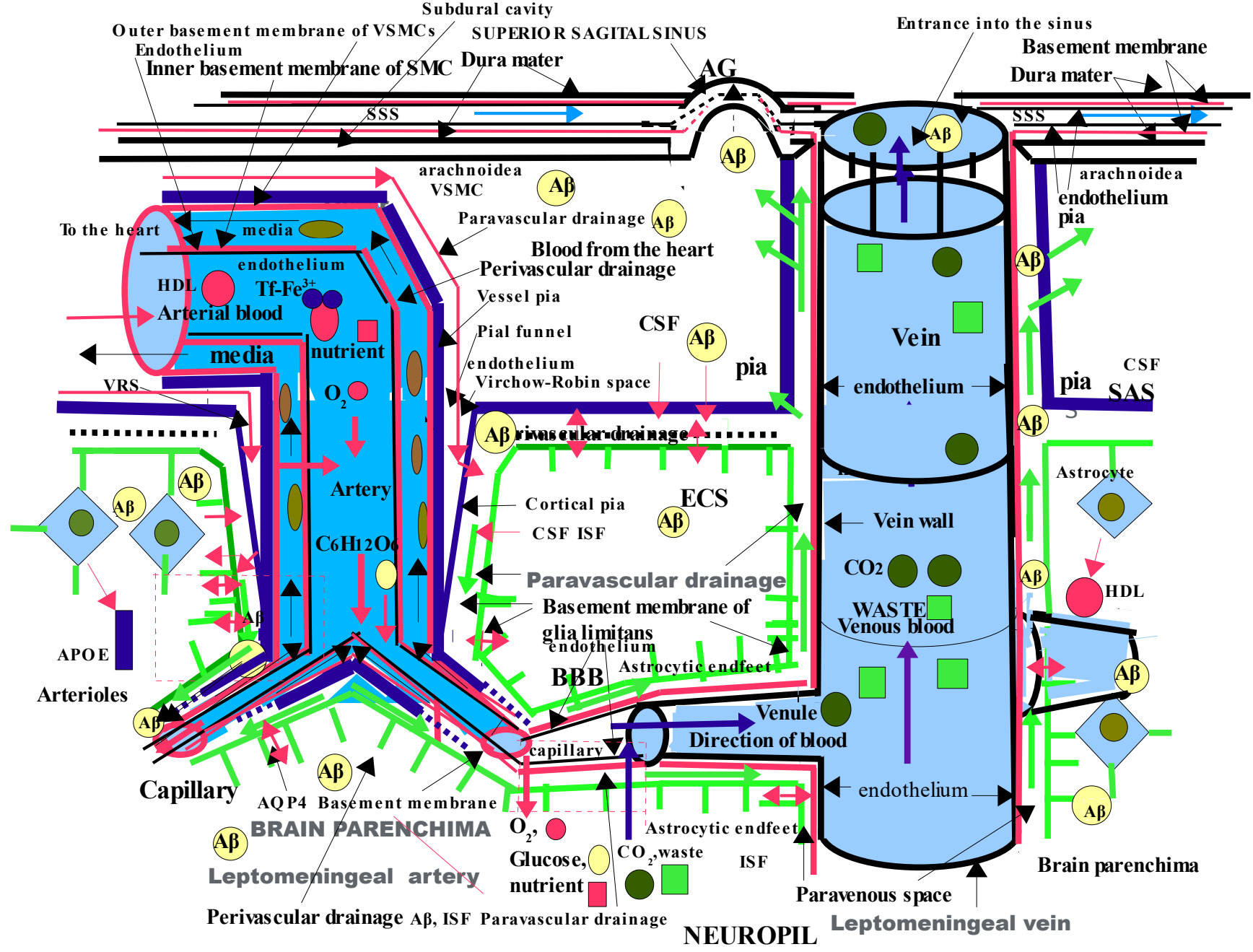

Fig.3. Schematic presentation of the $A \beta$, iron, and waste products drainage from the brain

CSF, cerebrospinal fluid; ECS, extracellular space; $A \beta$, amyloid beta; VRS, Virchow-Robin space; $\mathrm{O}_{2}$, oxygen; $\mathrm{C}_{6} \mathrm{H}_{12} \mathrm{O}_{6}$, glucose; $\mathrm{CO}_{2}$, carbon dioxide ISF, interstitial fluid; SMC, smooth muscle cell; AQP4, aquaporin 4, channellocated on astrocytic endfeet, important for $A \beta$ drainage; SAS, subarachnoid space; AG, arachnoid granulation; Tf-Fe ${ }^{3+}$, transferin-ferric ion complex; SSS, superior sagital sinus; BBB, blood brain barrier; this figure represents the additional survey of Fig.3. in the article GSR, 2019; 6:007-020 publishe online: March 31.2019. On the left side of the figure there is visible a rectange limited by small red lines-it in fact presents Fig.5. The other rectangle including capillaries presents Fig.4. BM at the capillary level is the result of the proximal integration of the outer and inner BM of VSMCs. HDL, high density lipoprote 


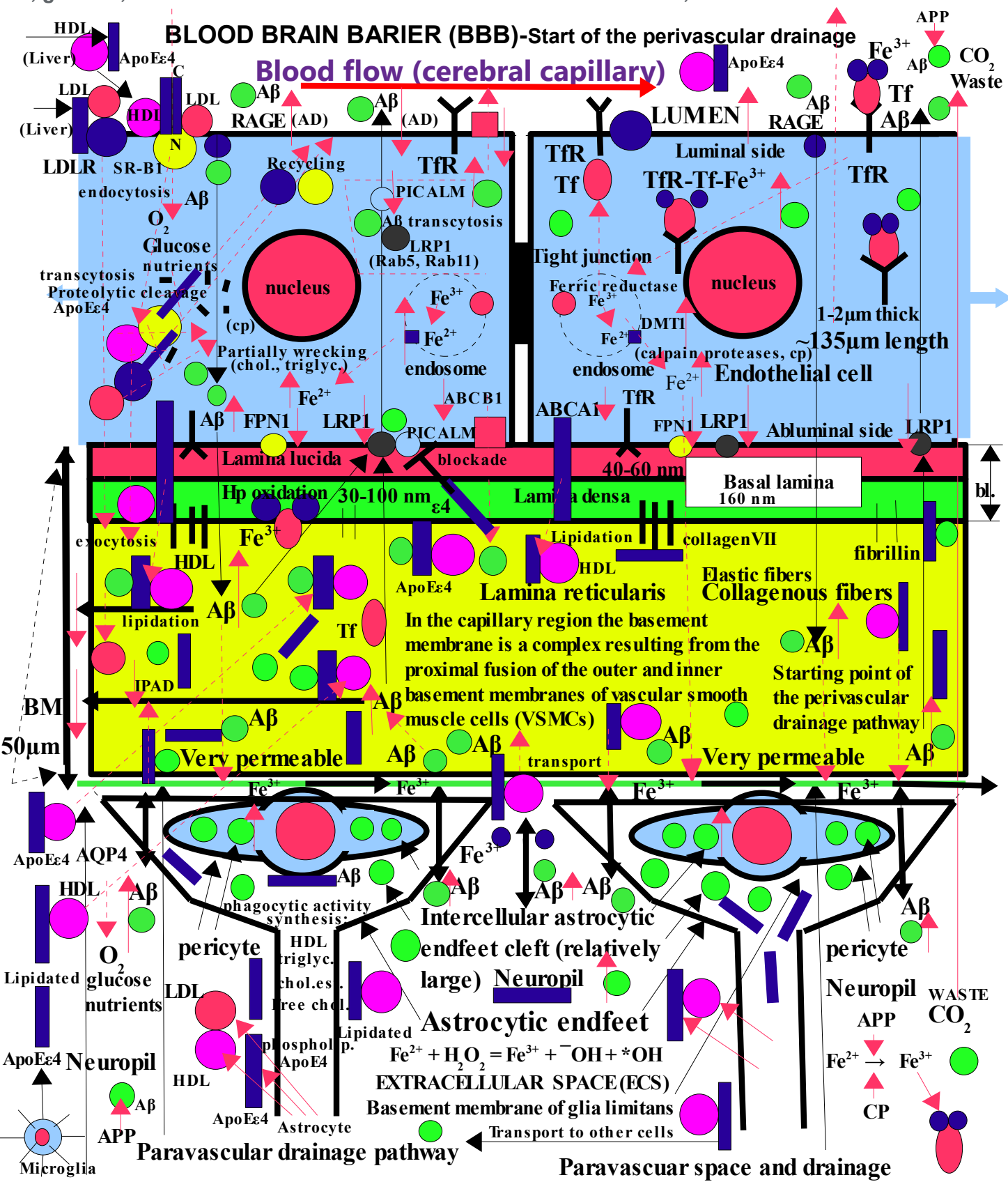

Pia disappears proximally

$1 \mathrm{~nm}=1 \times 10^{-} 9 \mathrm{~m}$, nanometre; $1 \mu \mathrm{m}=1 \times 10^{-} 6 \mathrm{~m}$, micrometre,micron;

\section{Fig. 4. Structure of the cerebral capillary basement membrane}

(longitudinal cross-section)

(effects of aging and AD)

On the upper part of the figure there are visible two endothelial cells connected by the tight junction. Above the luminal side of both cells by the red arrow is denoted the capillary lumen, anterograde blood flow direction, some receptors (TfR, RAGE) and $A \beta$ peptide molecules. Below the cells is visible the basement membrane which is composed of two layers, basal lamina and lamina reticularis; Hp, hephaestin. TfR receptor is localized on both luminal and abluminal membranes of brain capillaries; A part of HDL which enters into the EC is wrecked and a part continues to the L. Ret. ApoE can not be transported from the blood across the BBB into the neuropil. ApoE in the CNS is produced primarily by astrocytes. It is the principal lipid transporter in CSF. The extra and intracellular ApoE proteolysis has been discovered. 


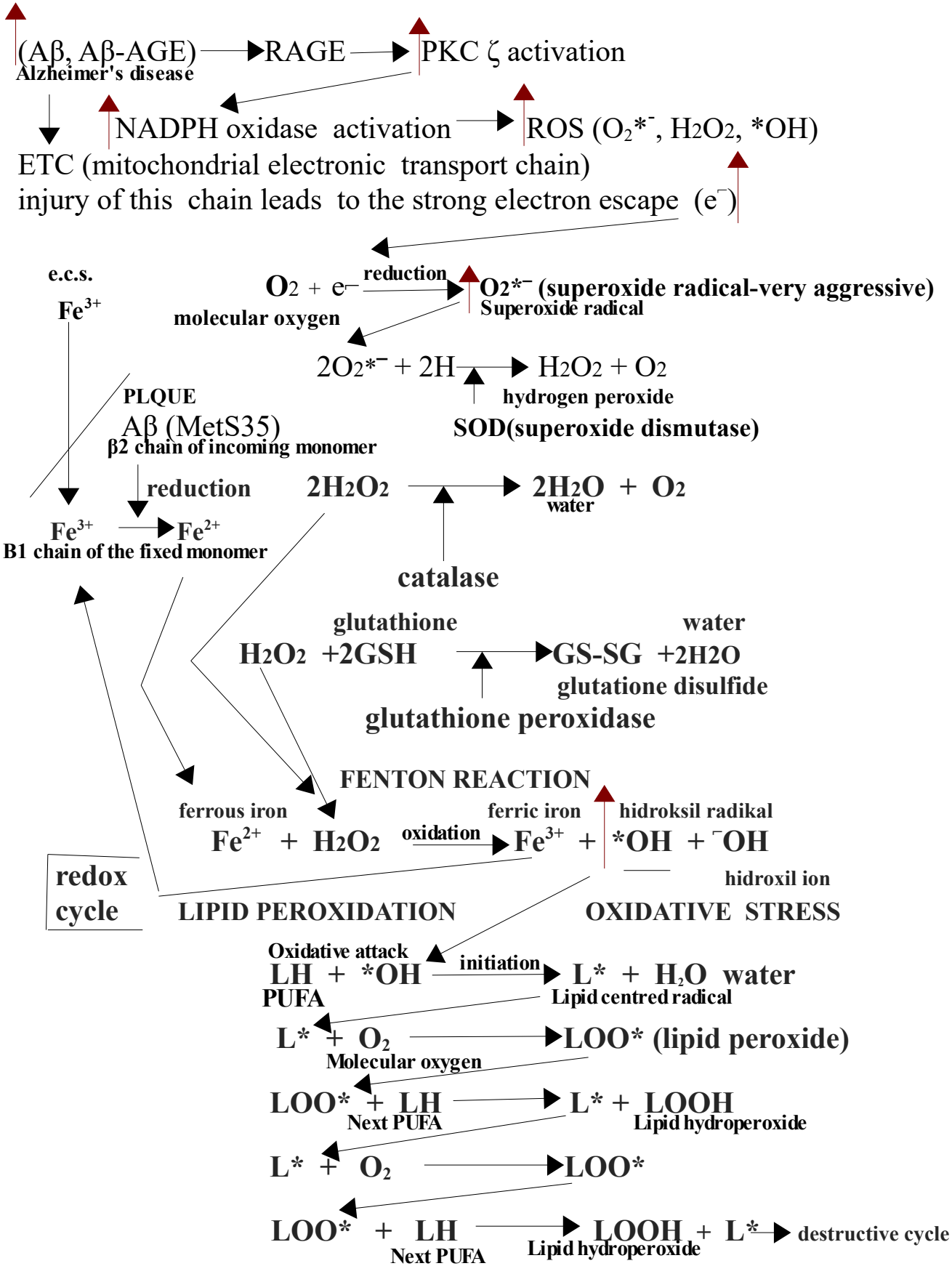

Fig. 5. Schematic presentation of important biochemical processes related to destructive free radical effects on essential molecular structures

PUFA, polyunsaturated fatty acid ; RAGE, receptor for advanced glycation end products; PKC protein kinase $\mathrm{C}$; NADPH oxidase, nicotinamide adenine dinucleotide phosphate-oxidase; ROS, reactive oxygen species; $\mathrm{O}_{2}^{*}$, superoxide radical; $\mathrm{H}_{2} \mathrm{O}_{2}$, hydrogen peroxide; $\mathrm{SOD}$, superoxide dismutase, strong antioxidant enzyme; catalase, enzyme, protects the cell from oxidative damage; GSH, glutathione peroxidase, enzyme, protection from oxidative damage; lipid peroxidation oxidative degradation of lipids; $\mathrm{Fe}^{2+}$, ferrous iron; $\mathrm{Fe}^{3+}$, ferric iron; e.c.s., extracellular space. 
The investigations show that the lipidation (covalent binding of lipid group to a peptide chain) of APOE 44 lipoprotein is significantly weaker as related to APOE\&2 and APOE\&3. APOE\&4-HDL particles are markedly smaller than the other two alleles. Otherwise, by aging, the ABCA1 (ATPbinding cassette transporter $\mathrm{ABCA1}$, colesterol efflux regulatory protein, CERP) expression and activity declines. APOE linked with the lipid (lipidated form, HDL, LDL) conditions and increases its interaction with $\mathrm{A} \beta$ ( $\mathrm{A} \beta$, residues 12-28; APOE, $\mathrm{N}$-terminal domain, residues 136-150) with the prompt transport of the whole complex by the effect of LRP1 (low density lipoprotein receptorrelated protein 1) and $\mathrm{ABCB} 1$ (P-glycoprotein, ATP-dependent translocase $\mathrm{ABCB} 1$ ) receptor. $\mathrm{ABCB} 1$ is located on the luminal and abluminal side of the endothelial cells membranes. It is an active mediator for the $A \beta$ peptide transport out from the brain. APOE $\varepsilon 4$ protein (lipidated by ABCA1, but significantly weaker than other two alleles), in relation to the other two alleles, has an evidently weaker linking with $A \beta$, and the generated complex (A $\beta / A p o E \varepsilon 4 / \mathrm{HDL}$ or LDL) transport is also weaker. The consequent result is stronger $A \beta$ accumulation in the structures of the perivascular space (PVS, basement membranes of VSMCs), as well as its stronger accumulation (the result of the consequent decline of the perivascular drainage) in the brain parenchima. On both levels, its aggregation is stronger. The LRP1 expression drop in the aged has been emphasized earlier ${ }^{17,18,19,-, 22}$ ).

It is important to emphasize that ApoE cannot pass through the $\mathrm{BBB}$. The central part of ApoE (CNS) is produced in the brain by astrocytes (mainly) and microglia. In the periphery, ApoE is produced primarilly by the liver. The pools of ApoE in the CNS and periphery practically exist independently from one another (Fig. 4) ${ }^{23,24}$.

On Fig. 4, well visible is the LRP1 effect on the A $\beta$ transcytosis from the basal compartment of the EC to the cell luminal membrane, and its clearance into the blood. Internalization of the soluble $A \beta$ from the lamina reticularis (capillary basement membrane) into the endothelial cell cytosol occurs by the interaction between LRP1 and ApoE. The effect of the latter, especially $\varepsilon 4$ allele, in fact, blocks this interaction and diminishes the intracellular entrance of LRP1/A $\beta$ complex. Bound with LRP1, A $\beta$ transcytoses passes across the BBB, and by the help of PICALM (Phosphatidylinositol binding clathrin assembly protein) and Ras-related protein Rab5 (Rab5) as well as Ras-related protein Rab11 (Rab11), the small GTPases, completes the mentioned clearance route (Fig. 4) ${ }^{25,-27}$ ).

On figure 4 is shown that HDL particles, carried by apolipoprotein ApoE\&4 (dominant allele in AD) incorporated molecules, arrive by blood in the $\mathrm{BBB}$ region where ApoE 84 recognizes the scavanger receptor class B type1 (SR-B1) and binds with it. Now occurs the endocytosis and internalization of the formed complex HDL/ApoEع4/SR-B1, and its transcytosis. During this event follows the dissociation of ApoE\&4 and its proteolytic degradation into a number of fragments, among them some very toxic for the cells. The proteolysis is mediated by the multiple intracellular proteolytic enzymes, among them especially the calpain proteolytic system (cp, calpain proteases). The obtained fragments are mainly toxic for a lot of cellular functions, for example the mitochondria oxidation (electron transport chain), cytoskeletal assembly, and stability. SR-B1 recycles and returns to the luminal membrane. Liberated HDL is partially wrecked and one part is used for the cell necessity. The other part continues its pathway to the abluminal membrane, and there is exocitosed into the capillary basement membrane. There it continues its binding with ApoEe4 (effect of ABCA1) produced by astrocytes, and exits from the basement membrane (BM) into the neuropil, or continues its movement along the perivascular pathway with the accepted A $\beta$. On Fig. 4 there is also presented the extracellular space with astrocytes which synthesise and secrete HDL and ApoE. There are also visible the $A \beta$ monomers. A major part of generated HDL is served for the cells necessity, and the other part enters into the perivascular drainage pathway and leaves the brain (Fig.4) ${ }^{28,-30}$ ).

\section{FENTON REACTION AND *OH GENERATION}

Along with the strong extracellular intracerebral $A \beta$ accumulation and aggregation, in $\mathrm{AD}$, in the brain region, occurs simultaneous accumulation of transition metals, among them especially iron ions. It is considered that the main reason for this event lies in the decreased drainage of iron, especially along the perivascular pathway. Linked with one transferin (Tf) molecule, two ferric iron ions $\left(\mathrm{Fe}^{3+}\right)$ at the level of $\mathrm{BBB}$ enter from the neuropil into the capillary basement membrane (as well as $A \beta$ and a number of other molecules and waste products), and continue their movement along the perivascular drainage pathway. In the case when in this pathway occurs an elevated concentration of $A \beta$ monomers (AD), which readily bind $\mathrm{Fe}^{3+}$ ions on their MBD (metal binding domain-His 6,His13,His14) the monomers mutual contacts and binding become much easier and frequent with the elevated $\mathrm{Fe}^{3+}$ reduction ("electron hop") in $\mathrm{Fe}^{2+}$ (MetS35 on one monomer by its oxidation dismisses an electron to $\mathrm{Fe}^{3+}$ ), with the consequent accelerated Fenton reaction with ${ }^{*} \mathrm{OH}$ radical spreading. ${ }^{*} \mathrm{OH}$ radical overproduction primarily leads to the dangerous oxidative attacks (electron stealing) on the VSMCs cell membranes with their deterioration and fatty acids peroxidation. Earlier in the text, in the paragraph about lipid peroxidation, these events were explained in detail (Fig.5) ${ }^{7,12-16}$ ).

\section{MAIN RECEPTORS INCLUDED IN THE PERIVASCULAR DRAINAGE}

Basement membranes of cerebral capillaries are the starting points of the perivascular drainage pathway. Biological membranes on the luminal side of endothelial cells of BBB are structures in which are embedded a number of vital receptors. 
Among them, it is necessary first to present the receptor for advanced glycation end products (RAGE) and explain its function. It is a transmembrane protein and belongs to the immunoglobulin superfamily. It can interact with multiple ligands such as advanced glycation end products (AGEs), high-mobility group protein (B) 1 (HMGB1), S-100 calcium-binding protein, Mac-1, phophatidylserine, and amyloid- $\beta$-protein. After binding $A \beta$, RAGE, located on the apical endothelial cell side, induces its internalization and transcytosis from apical to the basolateral side, and its partial entrance into the brain. A portion of $A \beta$ at the level of capillary basement membrane diverges from this route, and continues moving along this membrane and basement membranes of the perivascular pathway. In the case of elevated $A \beta$ concentration or the decline of the perivascular drainage, the $A \beta$ local accumulation and aggregation can occur. This can also happen in the case of the decline of the ApoEs4 lipidation. RAGE expression levels are increased in cerebral vessels endothelium during aging and in $\mathrm{AD}^{31}$ ).

LRP1 (low-density lipoprotein receptor-related protein-1) is a large endocytic receptor for many ligands located on the luminal and abluminal cell membrane of the BBB endothelial cells. It is involved in the lysosomal endocytosis and transcytosis of $A \beta$ which enters into the cells from the capillary basement membranes. In these membranes $A \beta$ arrives from the blood by RAGE activity. Bound with the angiopep 2, it can be transported from the blood into the brain, through the cell, as covalently conjugated drug. LRP1 expression levels decline in AD and in the course of aging. LRP1 is predominantly generated in the neurons and secreted into the interstitial fluid (ISF). It is abundantly expressed in neurons, glial cells and VSMCs. It has a great importance in maintaining brain homeostasis. After $A \beta$ endocytosis, it efficiently recycles back to the cell surface ${ }^{32,33}$ ).

LDLR ( low-density lipoprotein receptor) and SR-B1 (scavenger receptor class $B$ type 1 ) are surface receptors, located on the luminal side of the endothelial cell membrane. LDL and HDL particles are mainly synthesized in the liver and are carried through the body by circulating blood. However, they are also synthesized in the brain by astrocytes. The mentioned receptors internalize the LDL and HDL particles into the cells. After effective internalization, both receptors are recycled to the luminal membrane. Lipoprotein particles in the cytoplasm are subjected to the effects of lysosomes which break them down and recycle their constituents for different functions. A portion of lipoproteins probably pass intact from the cytosol, across the abluminal part of the cell membrane, then enter the basement membrane, and bound with $A p o E$, serve for $A \beta$ transport along the perivascular drainage pathway. It is also possible that lipoproteins, produced by astrocytes, cross the paravascular space and enter the capillary basement membrane $\left.{ }^{34,35}\right)$.

ABCA1 (ATP-binding cassette transporter A1) receptor, expressed at the abluminal side of the endothelium, induces the lipidation of ApoE, i.e. the binding of ApoE (res. 244-272) with molecules on the lipoprotein surface. It is an important factor for the efficient binding of $A \beta$ (res. 12-18) with ApoE (res.136-150). The developed complex $A \beta / A p o E / H D L$ or LDL, dependent on allelic structure, transports $A \beta$ along the perivascular drainage pathway. The transport which includes e4 allele is very weak, and consequently, $A \beta$ accumulation and aggregation in the drainage system, and generally, is strong. The expression of ABCA1 declines with aging and in $\mathrm{AD}^{36}$ ).

The receptor solute carrier family 40 member ferroportin 1 (FPN1), is embedded in the abluminal side of the endothelial cell membrane. It transports $\mathrm{Fe}^{2+}$ out from the cell. Immediately after its exit, $\mathrm{Fe}^{2+}$ becomes oxidised by hephaestin $(\mathrm{Hp})$ in $\mathrm{Fe}^{3+}$, and binds with transferin (Tf), locally present in the basement membrane. Iron in the form of $\mathrm{Fe}^{3+}$ cannot be transported along the perivascular drainage pathway. In the case of the drainage drop, $\mathrm{Fe}^{3+}$ also accumulates, and connected with the elevated values of $\mathrm{A} \beta$, is reduced in $\mathrm{Fe}^{2+}$ and enters the Fenton reaction. The ${ }^{*} \mathrm{OH}$ generation is the normal subsequent event. It is the only known iron exporter. Hephaestin is a transmembrane copper-dependent ferroxidase, functionally closely bound with the FPN1 receptor, responsible for the oxidation (electron loss) and transport of ferrous iron $\left(\mathrm{Fe}^{2+}\right)$ from the cell interior across its abluminal cell membrane. The obtained $\mathrm{Fe}^{3+}$ binds promptly with the locally present transferrin $(\mathrm{Tf})^{37}$ ).

The receptor P-glycoprotein 1, ATP-binding cassette sub-family B member 1 (ABCB1) is located on both sides of the cell membrane. Coordinated with LRP1, this receptor can transport intracellular $A \beta$ into the vascular lumen. Its role on the abluminal side is a questionable, but it is possible that here, it blocks the entry of $\mathrm{A} \beta$ into the cell. In $\mathrm{AD}$ and during aging its expression declines $^{38,39}$ ).

The transferin receptor (TfR) imports iron $\left(\mathrm{Fe}^{3+}\right)$ into the cell by internalizing the $\mathrm{Fe}^{3+} /$ transferin (Tf) complex through the receptor-mediated endocytosis. It is a transmembrane glycoprotein, located on the luminal and abluminal sides of capillary endohelial cells. According to some studies, it seems that during aging, there is a not exactly confirmed decrease in the sTfR concentration. (s, serum) ${ }^{40-42}$ )

Events related to the scavenger receptor class B type 1(SR-B1) are explained in detail in the paragraph about the ApoE\&4 apolipoprotein lipidation (Fig.4).

\section{THE CURRENT PREVENTION AND THERAPY FOR AD}

Unfortunately, it is evident that nowadays there still does not exist an effective prevention and therapy for $\mathrm{AD}$ and. The actual therapy for $\mathrm{AD}$ with cholinesteraze blockers (donepezil, rivastigmine, galantamine) is not satisfactory, and a number of other current therapeutics have a problematic effect. Currently, there are also attempts with immunotherapy, therapy with free radical scavengers and chelators (for example curcumin). The therapy 
with crosslinker breakers is also widely used. The correction of the fasting glucose level (nonenzymatic glycosylation of $A \beta$ retardation) has an important preventive role. Generally speaking, presently the therapy of $\mathrm{AD}$ includes antioxidants, AGE breakers, RAGE blockers and antiglycation compounds. Nowadays, there are actual investigations about the effects of alagebrium (ALT-711), aminoguanidine, DPTC, tiamine, benfotiamine, and piridoxamine. Related to the extracellular $A \beta$ degradation, the effects of neprilysine (metalloendopeptidase) and matrix-metalloproteinases 2, 3 and 9 inhibitors, are intensively investigated, as well as the functions of proteasomes and the ubiquitin-proteasome route. It is also necessary to mention vitamin C, vitamin E, superoxide dismutase (SOD), curcuma, Ginkgo biloba, and green tea (among the polyphenols found in green tea the most important is epigallocatechin-EGCG). $\left.{ }^{5,6,43-46}\right)$. In this paragraph regarding the current prevention and therapy it is necesary to emphasize the memantine as N-methyl-D-aspartate receptor (NMDAR) blokader. By this action it protects the brain cells from the harmful effects of, in $\mathrm{AD}$, elevated concentrations of released glutamate from damaged brain cells. It is also important to emphasize the cholinesterase blockaders: Aricept (donepezil hydrochloride), Axelon (rivastigmine), and Raminyl (galantamine hydrochloride). Apart from acetylcholine blockers and NMDA receptor antagonists, there are no other generally accepted medications or supplements. Previous researches on antioxidants, AGE breakers, RAGE blockers and antiglycation compounds haven't reached scientific evidence to be accepted as standard therapy for $\mathrm{AD}^{5}$ ).

It is justly to hope that the problem of the effective prevention and therapy of $\mathrm{AD}$ will be solved in the near future.

\section{CONCLUSION}

Due to the great importance of the $A \beta$ accumulation and aggregation in the $\mathrm{AD}$ brain, it is evident and logical that a number of recent investigators and their institutions increasingly take part in the research of the etiology, genetics, and patophysiology of this disease. These investigations are especially related to the failures of perivascular drainage and modes of its improvement.

\section{Conflict of InTEREST Statement}

The author states that the performance of this review entailed no issues representing a conflict interest. 


\section{LITERATURE:}

1. Morris AW, Sharp MM, Albargothy NJ, et al. Vascular basement membrane as pathways for passage of fluid into and out of the brain. Acta Neuropathol. 2016; 131: 725 -736.

2. Weller RO, Subash M, Preston SD, et al. Perivascular drainage of amyloid- $\beta$ peptide from the brain and its failure in cerebral amyloid angiopathy and Alzheimer's disease. Brain Pathol. 2008; 18: 253-266. 3. Albargothy NJ, Johnston DA, MacGregor-Sharp M, et al. Convective influx/glymphatic system: Tracers injected into the CSF enter and leave the brain along separate periarterial basement membrane pathways. Acta Neuropathol. 2018; 136: 139-152.

4. Aldea R, Weller RO, Wilcock DM, et al. Cerebrovascular smooth muscle cells as the drivers of intramural periarterial drainage of the brain. Front Aging Neurosci. 2019; 11:1.

5. Barić N. Increase in iron intracerebral concentration in patients suffering from Alzheimer's disease follows the rise of amyloid beta. Glycative Stress Res. 2019; 6: 7-20.

6. Barić $N$. Role of perivascular and paravascular drainage of $A \beta$, iron ions, and waste products from the brain. Glycative Stress Res. 2019; 6:159-174.

7. Oshiro S, Marioka MS, Kikuchi M. Dysregulation of iron metabolism in Alzheimer's disease, Parkinson's disease, and amyotrophic lateral sclerosis. Adv Pharmacol Sci. 2011; 378278.doi: 10.1155/2011/378278.Epub 2011 Oct 12.

8. Takahisa Kanekiyo, Huaxi Xu, Guojun Bu. ApoE and A $\beta$ in Alzheimer's disease: accidental encounters or partners? Neuron. 2014; 81:740-754.

9. Thomsen MS, Routhe LJ, Moos T. The vascular basement membrane in healthy and pathological brain. J Cereb Blood Flow Metab. 2017; 37: 3300-3317.

10. Raffaello A, Mammucuri C, Gherardi G, et al. Calcium at the center of cell sgnaling: Interplay between endoplasmic reticulum, mitochondria, and lysosomes. Trends Biochem Sci. 2016; 41: 1035-1049. 11. Gaspers LD, Bartlett PJ, Politi A, et al. Hormone-induced calcium oscillations depend on cross-coupling with inositol 1,4,5-triphosphate oscillations. Cell Rep. 2014; 9: 1209-1218.

12. Barić N. Role of advanced glycation end products (AGEs) on the reactive oxygen species (ROS) generation in Alzheimer's disease amyloid plaque. Glycative Stress Res. 2015; 2: 140-155.

13. Repetto M, Semprine J, Boveris A. Lipid peroxidation: chemical mechanism, biological implications and analytical determination. 2012; DOI.10.5772/45943

14. Felix R, Valentao P, Andrade PB, et al. Evaluating the in vitro potential of natural extracts to protect lipids from oxidative damage. Antioxidants. 2020; 9:231.

15. Gaschlera MM, Stockwell BR. Lipid peroxidation in cell death. Biochem Biophys Res Commun. 2017; 482: 419-425.

16. Panov A. Perhydroxyl radicals $\left(\mathrm{HO}^{*}\right)$ inducer of the isoprostane lipid peroxidation in mitochondria. Molecular Biology. 2018; 52:295-305.

17. Suidan GL, Ramaswamy G. Targeting apolipoprotein E for Alzheimer's disease: An industry perspective. Int J Mol Sci. 2019;20:2161.
18. Safieh M, Korczyn AD, Michaelson DM. ApoE4: an emerging therapeutic target for Alzheimer's disease. BMC Medicine. 2019; 17:64. 19. Frieden C, Wang H, Ho CMW. A mechanism for lipid binding to ApoE and the role of intrinsically disordered regions coupled to domain-domain interactions. Proc Natl Acad Sci USA. 2017; 114:6292-6297.

20. Zekonite J, Sakai K, Nicoll JAR. Quantification of molecular interactions between ApoE, amyloid-beta $(A \beta)$ and laminin: Relevance to accumulation of $A \beta$ in Alzheimer's disease. Biochimica et Biophysica ACTA (BBB) - Molecular Basis of Disease. 2016; 1862: 1047-1053.

21. Henry N, Krammer EM, Stengal F, et al. Lipidated apolipoprotein E4 structure and its receptor binding mechanism determined by a combined cross-linking coupled to mass spectrometry and molecular dynamics approach. PloS Comput Biol. 2018; 14:1-22.

22. Hubin E, Verghase PB, van Nuland N, et al. Apolipoprotein E associated with reconstituted high-density lipoprotein-like particles is protected from aggregation. FEBS Letters. 2019; 593:1144-1153. 23. Liu M, Kuhel DG, Shen L, et al. ApoE is not able to cross the $\mathrm{BBB}$, and the central ApoE is produced within the brain. Am J Physiol Regul Integr Com Physiol. 2012; 303:903-908.

24. Huynh TPV, Wang C, Tran AC, et al. Lack of hepatic ApoE does not influence early $\mathrm{A} \beta$ deposition: observations from a new ApoE knock-in model. Mol Neurodegener. 2019; 14:37.

25. Zhen Z, Sagare AP, Ma Q, et.al. Central role for PICALM in amyloid- $\beta$ bloo-brain barrier transcytosis and clearance. Nat Neurosci. 2015; 18:978_987.

26. Ma Q, Zhao Z, Sagare AP, et al. Blood-brain barrier-associated pericytes internalize and clear aggregated amyloid- $\beta 42$ by LRP1-dependent apolipoprotein $\mathrm{E}$ isoform-specific mechanism. Mol Neurodegener. 2018; 13:57

27. Zlokovic BV. Cerebrovascular effects of apolipoprotein E: Implications for Alzheimer disease. JAMA Neurol. 2013; 70: 440-444.

28. Huang Y, Mahley RW. Apolipoprotein E: Structure and function in lipid metabolism, neurobiology, and Alzheimer's disease. Neurobiol Dis. 2014; Dec: 72PA: 3-12.

29. Fung KY, Wang C, Nyegaard S, et al. SR-B1 mediated transcytosis of HDL in brain microvascular endothelial cells is independent of caveolin, clathrin, and PDZK1. Front Physiol. 2017; 8:841

30. Miyazaki T, Akasu R, Miyazaki A. Calpain proteolytic systems counteract endothelial cell adaptation to inflammatory environments. Inflammation and Regeneration.2020;40:5

31. Deane RJ. Is RAGE still a therapeutic target for Alzheimer's disease? Future Med Chem. 2012; 4: 915-925.

32. Storck SE, Bayer TA, Pietrzik CU. Endothelial LRP1 transports amyloid- $\beta 1-42$ across the bloodbrain barrier. J Clin Invest. 2016; 126 : 123-136.

33. Pflanzner T, Janko MC, Andre-Dohmen B, et al. LRP1 mediates bidirectional transcytosis of amyloid- $\beta$ across the blood-brain barrier. Neurobiol Aging. 2011: 32: 2323.e1-11.

34. Fung KY, Wang C, Nyegaard S, et al. SR-B1 mediated transcytosis of HDL in brain microvascular endothelial cells is independent of caveolin, clathrin, and PDZK1. Front Phisiol. 2017; 8:841. 
35. Zhang X, Sessa W, Fernández-Hernando C. Endothelial transcytosis of lipoproteins in atherosclerosis. Front Cardiovasc Med. 2018; 5:130.

36. Corona A, Landreth G. Lipidated APOE has effects on cognitive function that are independent of amyloid- $\beta$ pathology. Brain. 2015; 138:3470-3472.

37. McCarthy RC, Kosman DJ. Mechanisms and regulation of iron trafficking across the capillary endothelial cells of the blood-brain barrier. Front Mol Neurosci. 2015; 8:31.

38. Sita G, Hrelia P, Tarozzi A, et al. P-glycoprotein (ABCB1) and oxidative stress: Focus on Alzheimer's disease. Oxid Med Cell Longev. 2017; 2017: 7905486.

39. Brenn A, Grube M, Peters M, et al. Beta-amyloid downregulation MDR1-P-Glycoprotein (Abcb1) expression at the blood-brain barrier in mice. International Journal of Alzheimer's disease. 2011; 2011, Article ID 690121,6 pages.

40. Jong Weon Choi, Soo Hwan Pai, Moon Whan Im. Change in transferrin receptor concentrations with age. Clinical Chemistry. 1999; 45:1562-1563.
41. Huwyler J, Pardridge WM. Examination of blood-brain barrier transferrin receptor by confocal fluorescent microscopy of unfixed isolated rat brain capillarie. J Neurochem. 1998; 70:883-886.

42. Zhang Y, Pardridge WM. Rapid transferrin efflux from brain to blood across the blood-brain barrier. Journal of Neurochemistry. 2001; 76:1597-1600.

43. Marques F, Sousa JC, Sousa N, et al. Blood-brain-barriers in aging and in Alzheimer's disease. Mol Neurodegener. 2013; 8:38.

44. Barić N. Role of advanced glycation end products in Alzheimer's disease. Glycative Stress Res. 2014;1:68-83.

45. Marr RA, Hafez DM. Amyloid- $\beta$ and Alzheimer's disease: The role of neprilysin-2 in amyloid- $\beta$ clearance. Front Aging Neurosci. 2014; 6:187.

46. Rosenberg GA. Metalloproteinase and neurodegenerative diseases: Pathophysiological and therapeutic perspectives. Metalloproteinases in Medicine. 2015; 2: 39-50. 
